\title{
HEMANGIOSARCOMA OF THE SKIN
}

\author{
ARTHUR M. GREENWOOD, M.D. \\ Assistant Dermatologist, Massachusetts General Hospital \\ BOSTON \\ AND
}

THEODORE K. LAWLESS, M.D.

CHICACO

The case which we report was presented at the clinical meeting of the American Dermatological Association, at the Massachusetts General Hospital in Boston, in 1921, and as there was no general agreement as to diagnosis and there had not then been opportunity for careful study, the following report is presented. We are indebted to Dr. Frederick S. Burns, who presented the case, and to Dr. Harvey P. Towle, in whose service it occurred, for the opportunity to study it. The report of the discussion of the case at its presentation may be found in the October, 1921, number of the Archives of Dermatology and Syphilorogr, page 5.56 .

\section{REPORT OF CASES}

J. C., a manl, aged 62, born in Nova Scotia, married, a wood polisher, whose mother died of cancer, and whose father died of kidney disease, had five brothers, three dead; three sisters, all living; and one grandchild, who was well. There has been no condition similar to that of the patient in other members of the family, or any other skin disease. The patient was operated on at the Massachusetts General Hospital in 1920, and epididymectomy and vasectomy were performed for tuberculosis. As far as he knew, his skin was normal up to the time of the appearance of the present condition, and he thought there had been no birthmarks on his body.

The present condition began eighteen years previously, when he was 44 years of age, appearing on the face. The first thing he noticed was that the face was redder than normal, and he described the condition as a uniform redness which gradually covered the whole face and neck. From the onset, it had gradually spread over the neck, chest, abdomen, back, arms and buttocks. The patient thought that the spread had not been by direct extension from the original area but that it had appeared in new spots at some distance from the old ones. He was positive that the forearms were affected before the upper arms. He was of the opinion that there had been no extension for some months and our observation bore this out. There had been no subjective symptoms. The patient said that the eruption stood out much more distinctly after a bath or when he was cold.

Physical Examination. - The patient was well developed and fairly well nourished. The heart and lungs were normal. There was a right inguinal hernia, and the right testicle only was present. The urine showed a small amount of pus. The blood was normal; the blood pressure: systolic, 195. diastolic, 120; the blood Wassermann reaction was negative. The eruption or its sequelae involved the face, neck, chest, abdomen, back, buttocks, both 
folds of the axillae and the extensor surfaces of hoth arms and forearms. The skin of the active areas involved, seen from a distance, gave the appearance of a diffused. superficial, vascular nevus with varying shades of color, from a crimson red in the newer areas to a distinctly purplish-red in the older ones. There were seen on closer olservation:

1. Areas of cliffuse, fairly uniform purplish-red, in places a dusky blue, as is seen in asphyxia. These were on the chest and part of the alydomen and back. The color did not entirely disappear on pressure with the diascope.

2. Crimson red papules. slightly raised above the skin level. These were seen in or near the advancing horders. They varied from pinlead to pea si.e. Diascopic pressure did not efface them.

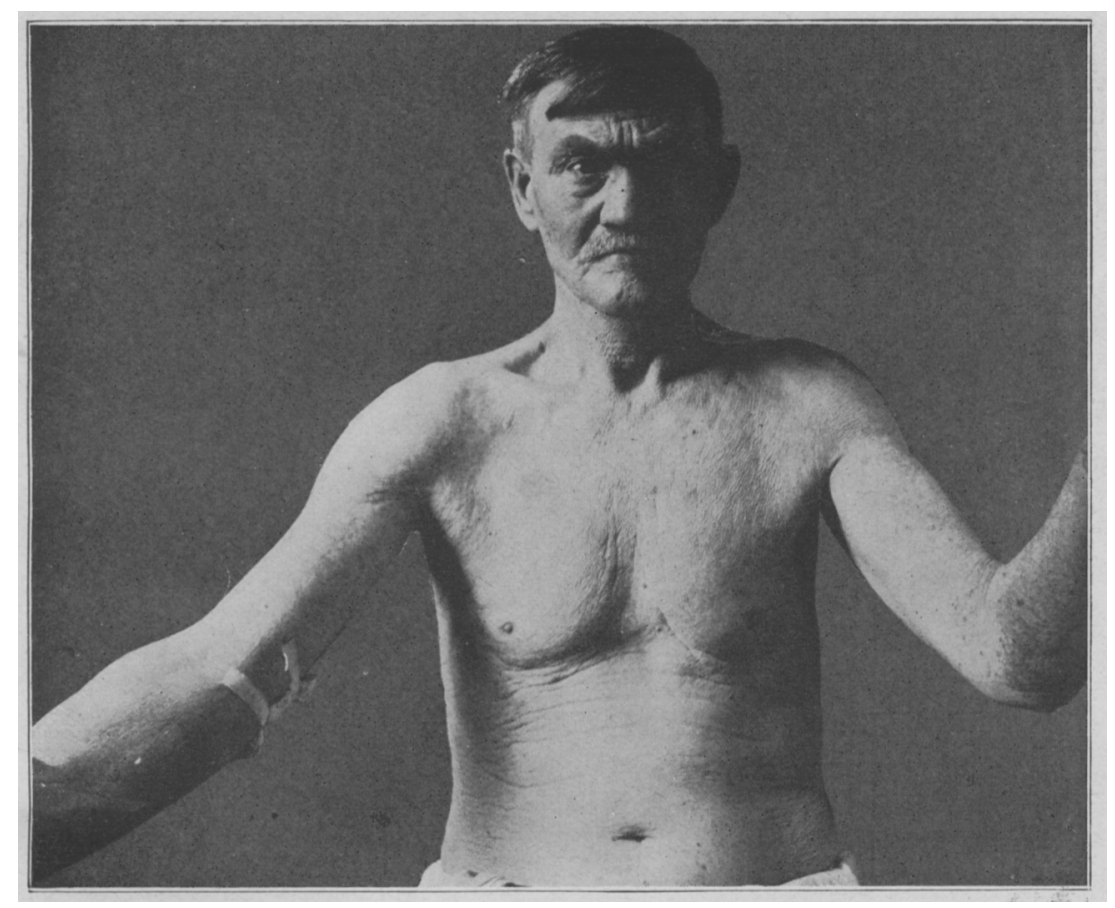

Fig. 1.-Front view, showing wrinkled, atrophic appearance of the shest arer which the process has passed. The color is a dusky hlue.

3. Many ringlike lesions in, and in advance of. the advancing lorder. The edges of these rings were clevated slightly ahove the skin level (approximately 1 mm.) and were about $1 \mathrm{~mm}$. wide. The centers were lower than the edges but nut depressed below the skin level. The process evidently consisted of a disappearance of the redness from the centers of the vasculat papules leaving a pronounced red border with a rather pater than normal skin color in the center. There was no primary grouping of vascular papules in circles. but the rings were evidently all formed as descrilect.

4. Pigmented lesions. These were circular, approximately pea-sized, brownish-yellow macules in, or just behind, the advancing borders. They were not marked and required fairly careful observation to he seen. They seemed much lighter in shade than those ordinarily made ly blood pigment. 
There were no distinctly atrophic spots. The centers of many of the vascular rings appeared whiter than normal and somewhat shrmken, but this seemed to us to lie more from contrast with the red, raised periphery than from actual atrophy. On the other hand, the extended purplish areas appeared distinctly atrophic and wrinkled and crossed with a fine network of lines, considerably more so than in the normal skin of that age.

There were no telangiectases on the parts of the lody affected by the growth. The general allance of the process apparently was by the appearance of the red papules in the normal skin beyoncl the areas of uniform redness. so that a schematic picture of the whole eruption, going from the normal skin to the oldest areas, would show: (1) normal skin; (2) vascular papules and rings

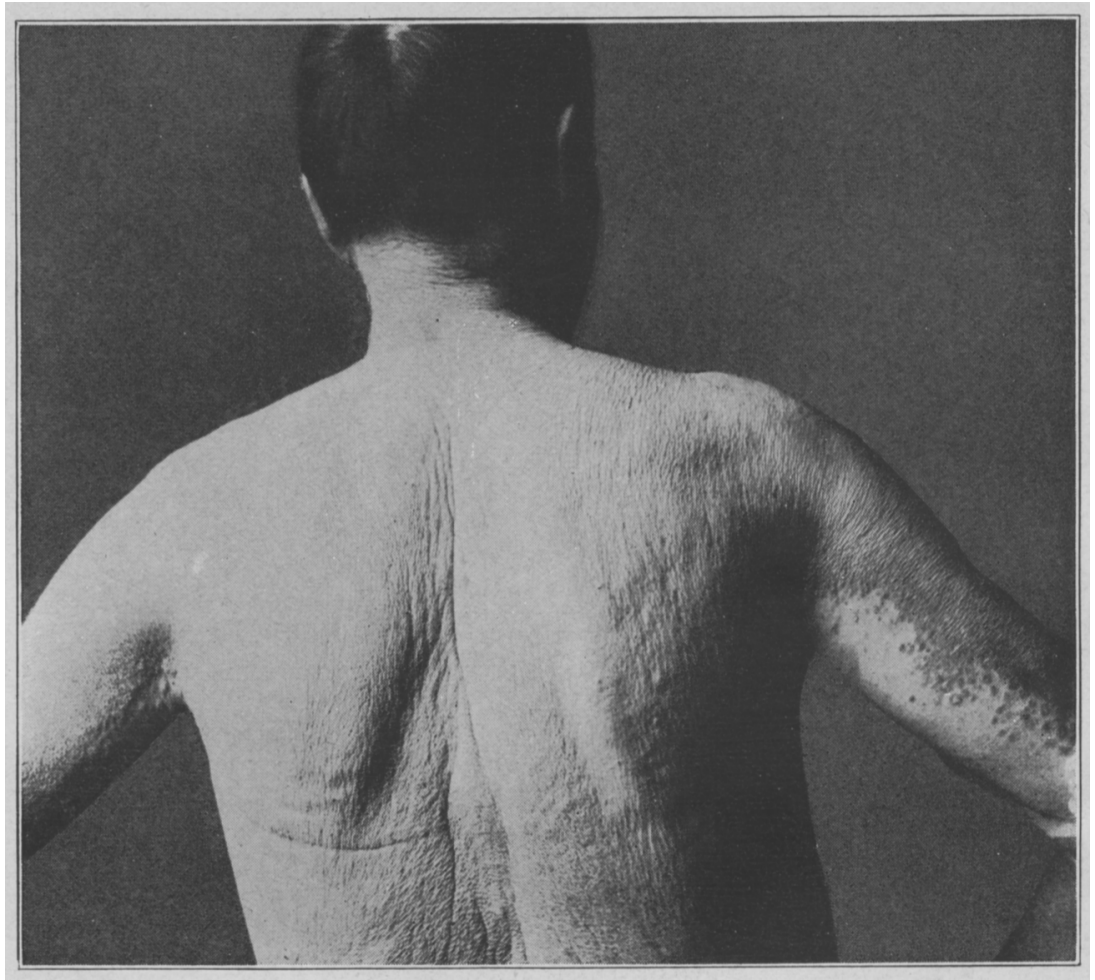

Fig. 2--Back view, showing older area on the lack and the active border on the upper arm. In this horder are seen the outlying vascular papules and rings. The color is almost crimson, with a slight bluish tinge.

with normal skin between: (3) pigmented spots on a more or less uniform redness: (4) rather mottled, purplish redness on a wrinkled, atrophic appearing skin. There was no descluamation in any place. The most recent lesions occurreci on the extensor surfaces of the arms and forearms and on the luttocks just external to the fold on either sicle. There was nothing to suggest "cayemne pepper grains" in any part of the lesion.

Below the huttocks, the skin presented a network of dilated capillaries and small reins on both thighs, legs and fect. This comelition did not resemble 
the condition on the upper part of the body and. while perhaps more pronounced than is ordinarily seen, was not uncommon in a lesser degree.

Histology. - The tissues, from which the microscopic description was made, were obtained from biopsies, 1 per cent. cocain being used for local anesthesia, with immediate fixation in 4 per cent. formaldehyd solution for twenty-four hours. The tissue was taken from the advancing borders, the areas of uniform redness, and the oldest, atrophic appearing areas.

From these tissues, both frozen and paraffin sections were made. The staining was eosin and hematoxylin, Weigert's elastic tissue stain, and van Gieson's and Mallory's connective tissue stains. Each of the foregoing methods of staining, aside from specifically stressing the tissues for which the characteristic reactions were obtained, emphasized the same general structure throughout.

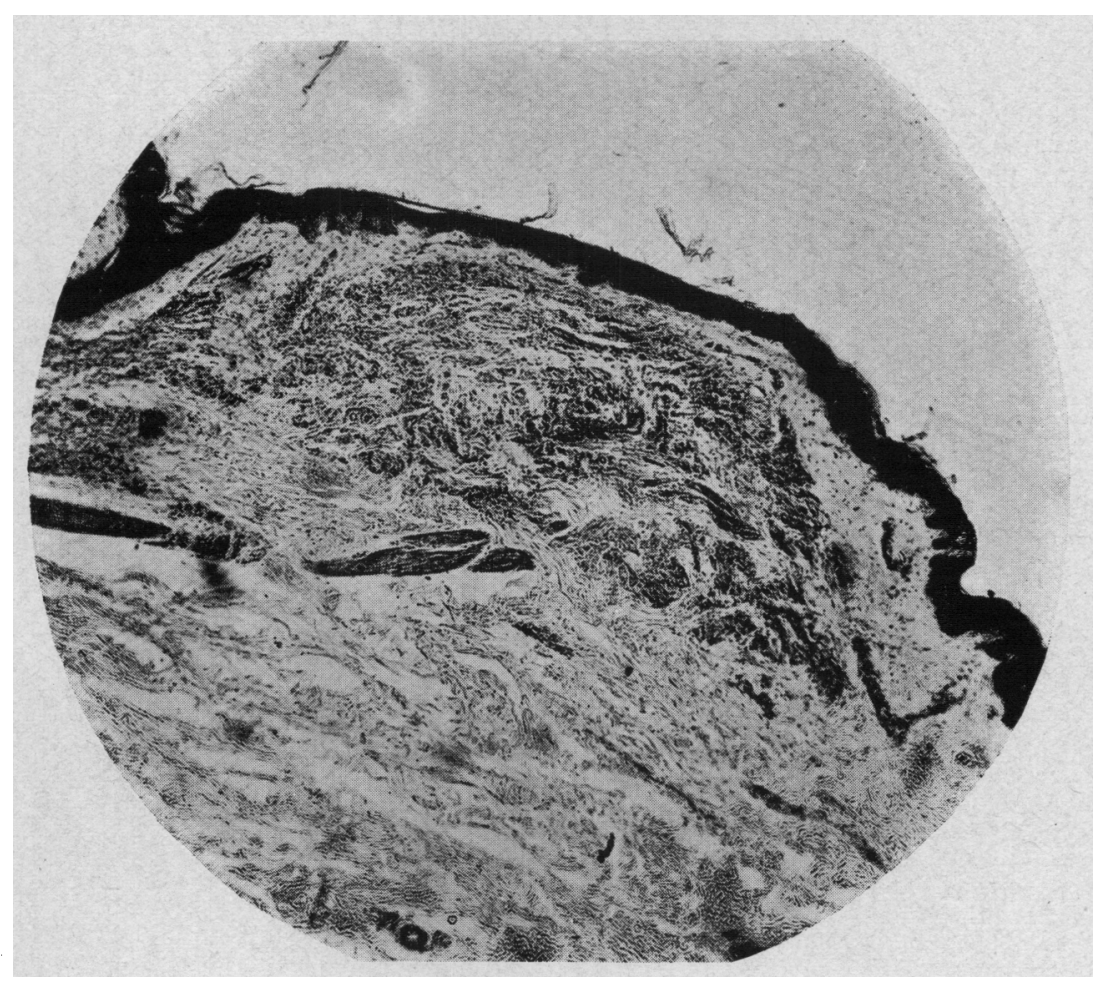

Fig. 3.--Low power photomicrograph showing location of the growth, its nevoid arrangement, flattening of the rete and keratosis of a follicular opening.

The epidermis gave no evidence of playing an active ròle in this condition or of being unduly affected by the activity of the process, with the exception of a slight increase in scale formation, a moderate degree of rete peg flattening over those areas of the corium where there was a proliferation of the neoplastic tissue, and plugging and keratosis of the follicular orifices.

The chief pathologic change was in the superficial corium, but occasionally the deep corium had also been invaded. Here we found, scattered at various levels, larger and smaller cell-rich areas. These cellular groups appeared mostly in an arrangement which was parallel with the epidermis, and were made up of islands and various sized cords and strands, in which were many vascular channels. 
The characier of the cells of this new formed tissue was constant throughout. A characteristic area presented fields of large ovoid to oral and, in places. flattened cells lining definite channels, and, in other instances, grouped and whorled and showing marked tendencies to line spaces in the tissue. The most striking component of these cellular masses was the presence of many large cells containing from one to five nuclei. These cells, as to nuclei and cytoplasm, resembled the definite endothelial celis but contained a larger amount of cytoplasm. This cytoplasm was finely granular and had a definitely reticulated appearance, and, like the cytoplasm of the cells lining the definite channels, was moderately basophilic in character. In man! places. these multi-

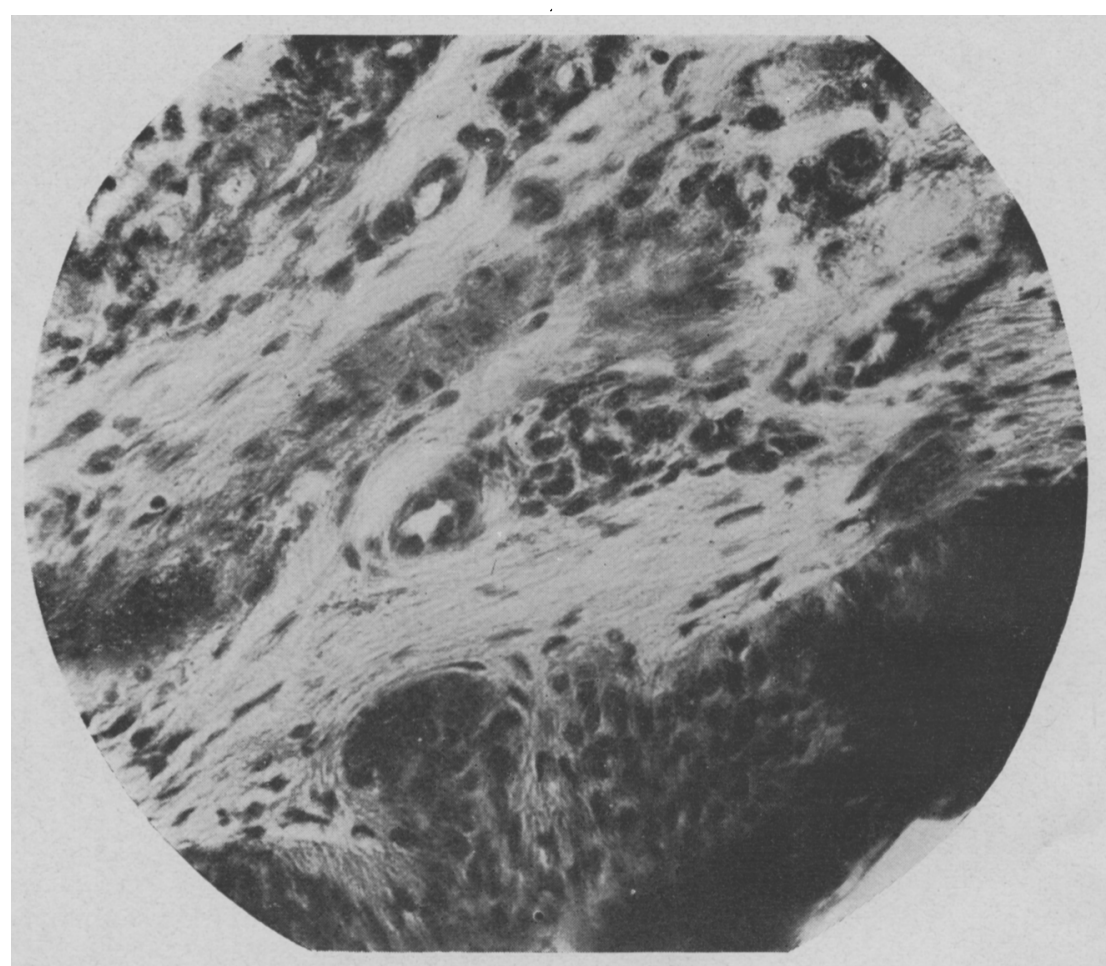

Fig. 4.-High power photomicrograph showing the newly formed ressels cut in cross section and longiturlinally.

nucleated cells were sending out proteplasmic processes which apparently marked the first step in the formation of vascular channels. There were areas in which we found groups of these multimucleated cells alparently fused, or in the act of fusing, and a definite channel being formed by this act.

Within these proliferating areas, we found, here and there, either singly or in groups. cells of the 1 mphocyte series with a well formed, round to oval, deeply staining nucleus, and a small rim of acidophilic protoplasm. These cells were in the lympl spaces. Here and there were seen various sized. finely granular areas, with a reticulated appearance and without nuclear structures. 
The comnective tissue hundles were normal in appearance. Iut the spaces between them were increased. In those areas in which the number of new cells was large, the connective tissue fibers were diminished. The elastic tissue was apparently normal in quality although there was noted an increase in the amount of elacin. This, however. might easily have been a senile change.

The glandular structures were apparently normal, with an occasional invasion of the contiguous tissues by the neoplastic cells and with some follicular keratosis at the epidermal portions. There was nowhere to be seen the slightest evidence of an inflammatory reaction. The entire process impressed one as a postembryonal proliferation of endothelial cells, noninflammatory in nature, and the condition may he denominated hemangiosarcoma, or hemangio-endothelioma, with a distinctly nevoid arrangement.

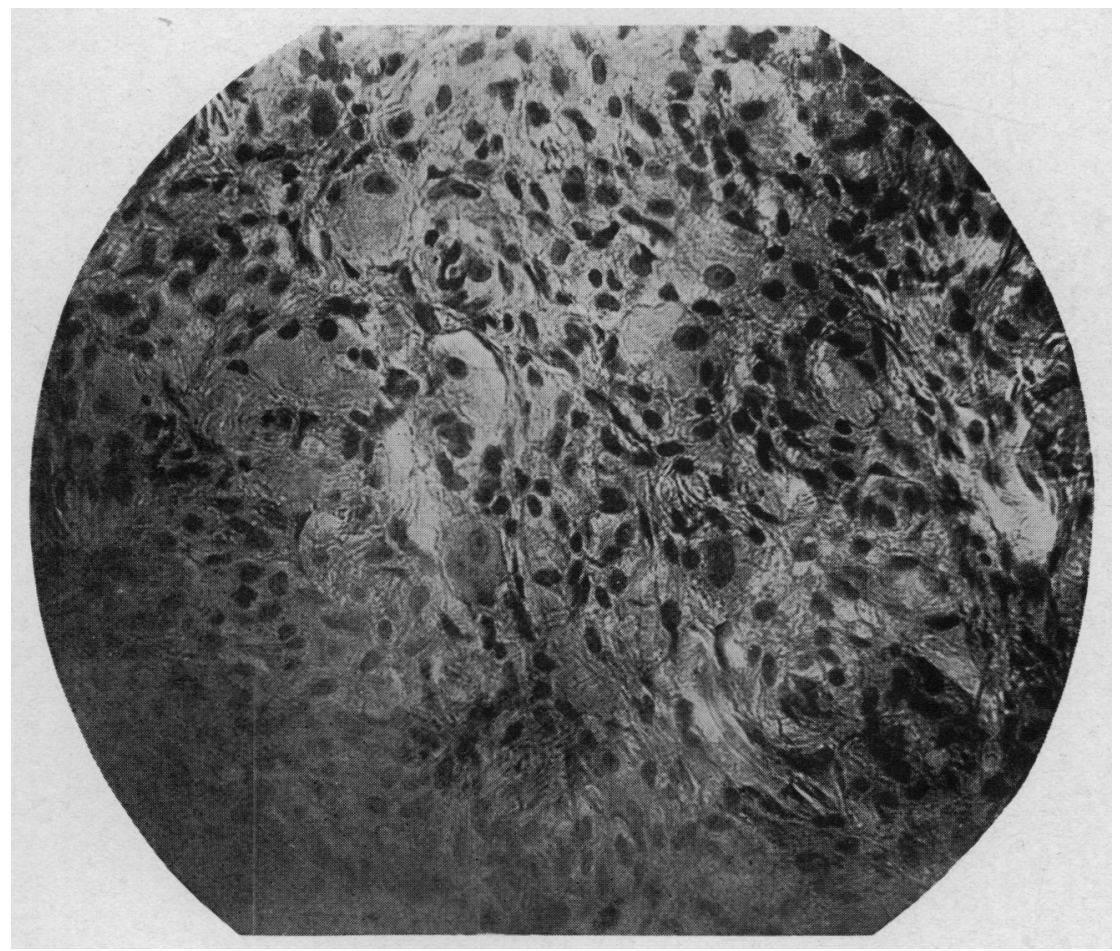

Fig. 5.-High power photomicrograph showing the large endothelial tumor cells, one of them with two nuclei and sending out a protoplasmic process.

In 1894, Dr. James C. White" reported a case of "so-called angioma erpiginosum," an abstract of which, with the histologic report, follows:

A hoy, aged 12 years, had at birth. a "purplish-red mark" below the right shoulder blade. It increased slowly in size in an upward direction until he was 4 years old, when another spot no larger than the head of a pin appeared near the original one, which gradually became larger. Since then others had continued to appear and grow, up to the time of examination. The process began in the form of minute elevated points, of a bright red, which

1. White. J. C.: J. Cutan. Dis., December, 1894. 
slowly increased in size mutil they were from one-eighth to one-sixth of an inch (3 to $4 \mathrm{~mm}$.) in diameter. At this stage, they were elevated from one-twelfth to one-eighth of an inch ( 2 to $3 \mathrm{~mm}$.) above the general surface. They were bright red, varying from scarlet to carmin, which could he made to disappear only partially by long pressure, and were of firm consistence. Having attained this size, they unclerwent involution at the center, which slowly sank down as the growtl spread peripherally. In this way, rings were formed, and the disease progressed as an annular elevated margin. ahout one-eighth of an inch $(3 \mathrm{~mm}$.) in breadth, slowly creesing outward, until. by confluence with other lesions, the regular circular shape was lost. Within the ring. the stin had apparently returned to its natural condition except in

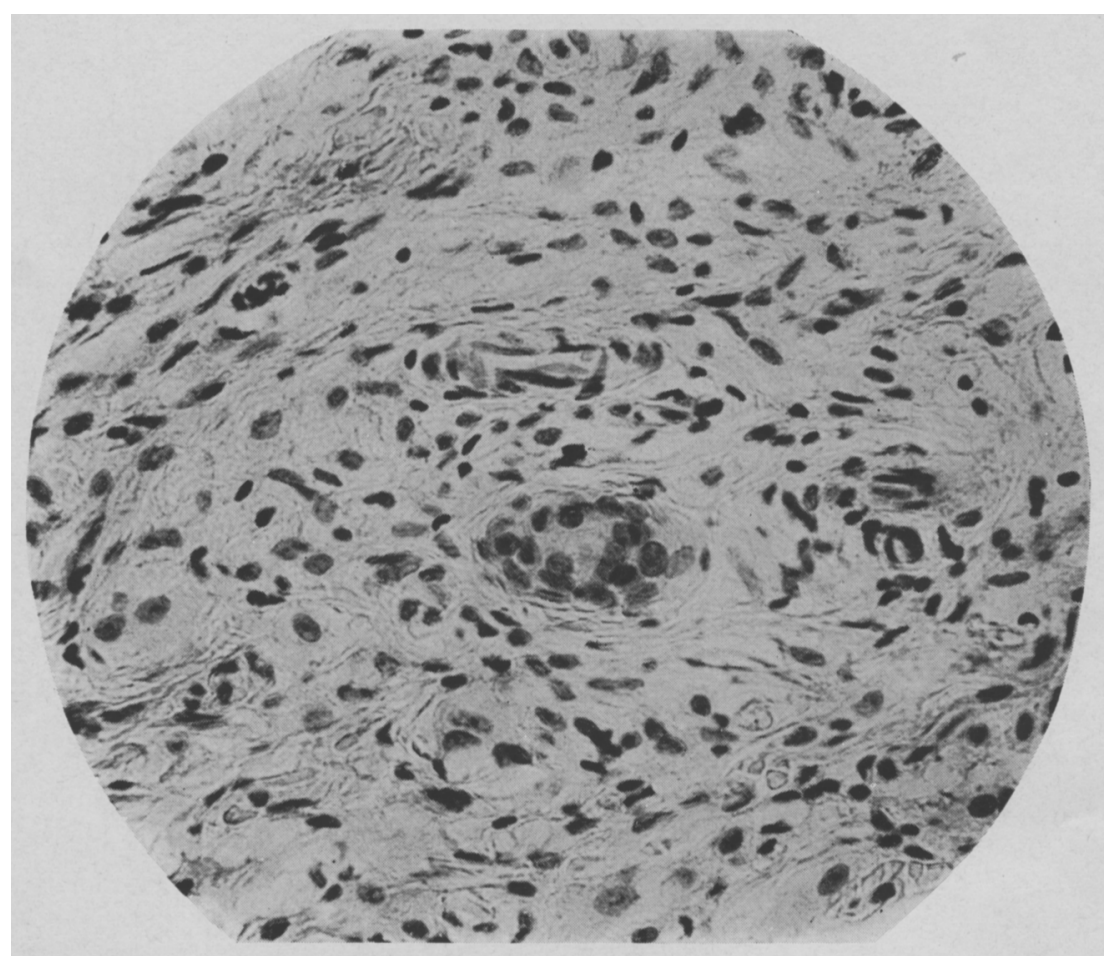

Fig. 6.- High power photomicrograph showing whorl of tumor cells with imperfect attempt at ressel formation.

color, which remained of a dull purplish or dusky hue. New foci, in the shape of minute points, appeared at some distance from the older areas, and assumed the same anmular mode of progression, with central involution. The elevated margin or ring preserved a uniform breadth alout its whole circumference. New foci were continually developing some distance. from one eigloth to one third of an inch ( 3 to $8 \mathrm{~mm}$.), beyond these older areas, which in turn were converted by central involution into the annular forms. The tisste in all stages of activity, the small papules and the rings in all their parts, presented the same character-a firm, smooth, elevated structure, varying in color from liright red to claret. The central areas after involution sank down to the normal level but remained stained, of a dull purplish-brown tint. 
Histologic Report (Dr. Darier).-The epidermis was composed of its ordinary layers unaltered, and not infiltrated by the numerous migratory cells, as occurs in inflammations.

Examination by low power revealed a lesion occupying the whole extent of the derma, and consisting of a mass of cells deeply colored by the reagents. These masses were more or less sharply defined at their borders, and presented diverse outlines, circular or ovoid, with margins, festooned or angular, or drawn out into trails, which, in sufficiently thick sections, seemed to form, by ramification or anastomosis, a coarse network. In the deeper layer of the corium, on the border of the hypoderm, where the sweat glands lie, the masses of cells were abundant and large and were often seen in immediate contact with the glomerulas. The tubes of the gland were never invaded or destroyed.

With the high power lens, the cells composing thes masses were seen to be fusiform, aplastic or angular in shape. Their protoplasm was aloundant, and the nucleus was generally oval in form. This was manifestly no question of epithelial cells, but of cells having a mesodermic origin. There was persistence of elastic tissue. In all the masses, the flattened cells had a tendency to group themselves concentrically about a certain number of centers. Such a center was often made up of two or three cells of the same nature attached at their edges and thus forming a canal. At two or three points, the center was occupied by a cell much larger than the others with several nuclei (a vasoformative cell?).

It appears, then, that we are dealing with a new formation of capillaries at the expense of the elements of the neoplastic tissue. How, then, is this lesion to be classed, and what name shall be given it? A neoformation, noninflammatory, composed of cells of the type of young connective tissue cells, should necessarily bear the name of sarcoma. But it will be observed that we are in the presence of an unusual form of sarcoma, not massed in a single tumor, but reticulated and infiltrated as a network. There is, moreover, to be noticed the tendency which the cells of this sarcoma have to form networks and clusters of more or less dilated capillaries, that is to say, to transform themselves into a true angioma. The title of this new formation might well be sarcome angioplastique réticulé. The information received, that this tumor started on the surface of a nevus, leads one to think that this is a nevus à structure de sarcome angioplastique devenu envahissant.

Comment.-Professor Councilman and Dr. Bowen, who examined sections from this case, found the epidermis and the hair follicles and sweat glands normal. The special pathologic condition consisted of groups of cells distributed in the corium, fairly well circumscribed and, in general, arranged parallel to the surface. The cells making up these groups were large, their nuclei oval in form and having something of the appearance of the nuclei of epithelioid cells. Various changes in the vessels could be made out. These consisted in swelling and proliferation of the endothelial cells of the vessels. frequently combined with proliferation of the cells on the outside. These vascular changes apparently affected small veins and capillaries. There was no evidence of anything corresponding to inflammation.

They noted, as a peculiarity in the process, the presence of small granular masses here and there in the cell groups. In the centers of some of the cell groups, a number of cells could be seen which were more granular and did not stain as brightly as the surrounding cells, and every gradation between this and total necrosis was found. Regarding the process as a whole, they said that it was one affecting the vessels of the skin; that it seemed to begin by a 
proliferation of the endothelium accompanied by a corresponding proliferation of the perithelium and that the degeneration in the older areas seemed to show that, with the advance of the cell proliferation, there was a corresponding degenerative process going on. They state: "From a purely histological consideration of the growth it may be compared to an angiosarcoma, it being understood that with this name only the histological appearance is taken into consideration."

It seems probab'e that the degenerative process which the last investigators found corresponds to the areas of involution which were so evident in both these cases. Similar granular areas were found in our sections.

At the discussion of this case at the meeting of the American Dermatological Association, two conditions were chiefly considered: angioma serpiginosum and poikiloderma atrophicans vasculare. This case differs from those included by $W$ ise $^{2}$ under angioma serpiginosum, in the following points: $(a)$ the absence of minute puncta; $(b)$ the absence of telangiectases; $(c)$ the fact that the outlying lesions were raised; $(d)$ in the method of formation of the vascular rings; $(e)$ in the histology, angioma serpiginosum being, to quote Wise, "a low grade inflammation . . . with secondary effects on the epidermis . . . in no sense an angioma."

The second condition considered was poikiloderma atrophicans vasculare, an excellent description of which, with the literature, is presented in Lane's article. ${ }^{3}$ Our case differs from this condition in that there are: $(a)$ no petechiae; $(b)$ no telangiectases; $(c)$ no reticular pigmentation; $(d)$ no itching nor ulceration. There is nothing in this case at all suggestive of roentgen-ray dermatitis, which is marked in poikiloderma atrophicans vasculare, and, as Dr. Lane pointed out in the discussion, the eruption in this case is most intense at the borders, while in poikiloderma atrophicans vasculare it is most intense at the center and fades toward the borders.

As to the pathologic classification, Ewing ${ }^{4}$ says:

Hemangioma hypertrophicum (Ziegler) is a cellular form of capillary angioma occurring chiefly in the skin. It consists of a large number of small vessels lined by hypertrophic and neoplastic endothelium. The vessels usually maintain a scanty lumen but the proliferation of endothelium may obliterate the lumen and yield compact groups of cells. In this form, the tumor is virtually an endothelioma and in this and the transitional forms, it may be designated as hemangio-endothelioma. Pure tumors of this type are usually progressive and if very cellular may exhibit local malignancy.

2. Wise: J. Cutan. Dis., 1913, p. 725.

3. Lane, J. E.: Poikiloderma Atrophicans Vasculare, with Report of a Case by Oliver S. Ormsby, M.D., Chicago, Arch. Dermat. \& Syph. 4:563 (Nov.) 1921.

4. Ewing. James: Neoplastic Diseases, Philadelphia, W. B. Saunders Company, 1919, p. 221. 
Mallory ${ }^{5}$ defines endothelioblastoma as "a tumor of mesenchymal origin of which the cells tend to differentiate into flat endothelial ceils and to line vessels, cavities and surfaces." He says:

The endothelial cells of a hemangio-endothelioma tend to form blood vessels as they do under normal conditions. The vessels of the tumor may be capillary in type or cavernous, or of any gradation between these two exiremes. The capillary hemangio-endothelioblastoma is relatively common. often congenital and frequently grows with considerable rapidity. It is always infiltrative in growth.

(a) In the large vessels the endothelial cells sometimes thicken up into two or more layers.

(b) Rarely the endothelial cells grow out into the lumina of the vessels in the form of papillary projections in which the endothelial cells sometimes accumulate in concentrically arranged masses or whorls. One tumor of this type started from a vascular nevus of the eyelid, invaded the orbit and destroyed the eyeball. Another, reported by Borrmann, recurred repeatedly at its site of origin beneath the breast after excision, and finally gave rise to multiple metastases in the lungs.

(c) If the capillary vessels are occluded or injured in any way so that the blood ceases to circulate in them, the endothelial cells continue to proliferate, but as they are no longer connected with the blood stream they do not form vessels. Instead, the cells collect in rows, groups, and especially on concentric masses or whorls.

The hemangio-endothelioblastomas are often congenital and frequently, perhaps always, arise from abnormalities of the blood vessels, especially from vascular nevi. They occur most often in the skin and subcutaneous tissue but may originate also in the muscles, nerves, liver, spleen, brain, bone marrow, eic. They are to be regarded on the whole as benign growths, although locally destructive, because their manner of extension is by infiltration of the surrounding tissues and by growth within and along blood vessels. Apparently but one case of metastasis is on record.

Dr. J. Homer Wright considers that conditions similar to this case are distinguished from the vascular nevi by the fact that in vascular nevi each nevus cell forms part of the wall of a blood vessel. When the endothelial cells form masses and are not confined to vessels, this fact takes the growth out of the class of vascular nevi and places it among the sarcomas, or the enclotheliomas.

Oertel ${ }^{6}$ says of angiosarcoma :

When the endothelial cells of angiomata assume greater activity (than in lemangiomata) and newly formed vessels remain incomplete, aborted, or when these cells only attempt to unite to vessels and grow more or less diffusely and undifferentiated, we speak of them as angiosarcomata.

5. Mallory: Pathologic Histology, Philadelphia: W. B. Saunders Company, 1914 , p. 379

6. Oertel, Horst: General Pathology, New York, Paul B. Hoeber, 1921, p. 285. 
It has seemed to us that the outlying vascular papules in this case and the appearance of the growth in new areas at some distance from the old ones should be considered as metastases. Such a superficial process could hardly extend by continuity without showing scme external change in the skin.

We must conclude, then, that Dr. James C. White's case and this one are similar, both being due to the manifestations in the skin of a tumor process, the tumor cells arising from mesoblastic tissue and showing a tendency to form vascular channels and to metastasize in the skin. Whether one calls it an hemangiosarcoma or an hemangioendothelioma is a matter of nomenclature. The nevoid arrangement of the growth in this case would suggest its originating in a nevus, and Darier evidently considered Dr. White's case as of that origin. The patient's observation as to the absence of any nevi might easily be inaccurate. It is evident that the cases of angioma serpiginosum, so-called, and these two cases do not belong in the same category; and, if this condition is to have a dermatologic name, it would seem to be more in keeping with the findings to confine the name angioma serpiginosum to cases of this class, since it is both an angioma and serpiginous; while the cases included at present under that name are neither. 